\title{
Original Artide
}

\section{Production of a Semi Ready-to-Eat Shrimp Soup Powder and Assessment of Its Shelf Life}

\author{
Ghorban Zarehgashti $^{1, *}$, Yasaman Etemadian ${ }^{1,2}$, Ali Reza Valipour ${ }^{1}$, Masoumeh Rahnama ${ }^{1}$, Fereshteh Khodabandeh $^{1}$, Afshin Fahim ${ }^{1}$ \\ 1- Inland Waters Aquaculture Research Center, Iranian Fisheries Science Research Institute, Agricultural Research, Education and Extension \\ Organization (AREEO), Bandar Anzali, Iran \\ 2- Young Researches and Elite Club, Rasht Branch, Islamic Azad University, Rasht, Iran
}

\section{A B S T R A C T}

Background and Objectives: Macrobrachium nipponense are wetland crustaceans. The shrimp is rich in protein and unsaturated fatty acids (FAs). Therefore, the aim of this study was to use M. nipponense as a supplement for the preparation of a new soup.

Materials and Methods: Nearly $40 \mathrm{~kg}$ of $M$. nipponense were harvested from Anzali Lagoon, Northern Iran. Shrimps were washed and dipped in $\mathrm{NaCl}$ solution $(10 \% \mathrm{w} / \mathrm{v})$ with a ratio of 1 to 2 at boiling temperature for 3 min. Then, these were cooled down for 10 minutes and dried by a cabinet-type air dryer at $70{ }^{\circ} \mathrm{C}$ for $6 \mathrm{~h}$. Dried meats of shrimps were crushed using grinder. Nearly $4 \%$ of the crushes were combined with other ingreadients of the shrimp soup. Each $100 \mathrm{~g}$ of the soup powder was packed in a metalized film under vacuum and stored at room temperature for 6 months of storage.

Results: Results have shown that dried shrimp meats include useful compositions such as saturated FAs ( $\Sigma$ SFA; 33.36 $\pm 2.5 \%$ ), monounsaturated FAs ( $\Sigma$ MUFA; $21 \pm 1.6 \%$ ) and polyunsaturated FAs ( $\Sigma$ PUFA; $38.92 \pm 2.1 \%$ ). The protein content in dried shrimp meats was high $(72.74 \pm 1.99 \%$ of dry weight). Chemical parameters of the samples such as thiobarbituric acid (TBA), peroxide value (PV), total volatile base nitrogen (TVB-N) and free fatty acid (FFA) increased and quality of the packaged soup color decreased with increased storage time $(P<0.05)$. The sensory evaluation (color, odor, flavor/taste and texture) of the samples has shown that these parameters are more acceptable during the first month of storage than other months. The total number of bacteria and fungi was respectively calculated as 4.1 and $3.79 \mathrm{cfu} / \mathrm{g}$ of sample during 6 months of storage.

Conclusions: In this study, use of $4 \%$ of the dried shrimp meats as supplement made a great taste in the soup. Furthermore, appropriate packaging under vacuum and use of metalized polyethylene films increased the shelf-life of the soup powder.

Keywords: $M$. nipponense, Semi ready-to-eat, Shrimp soup, Shelf-life

\section{Introduction}

Soup (e.g. fish and shrimp soups) is a popular nutritious food for people worldwide. Fishs and shrimps are rich in polyunsaturated fatty acids (PUFA) such as eicosapentaenoic acid (EPA) and docosahexaenoic acid (DHA) (1). These PUFA are sensitive to environmental conditions during the storage time (2). Generally, preparation of shrimp soups in home kitchens is a time-consuming job. Furthermore, it is difficult to prepare soups with good flavors from raw shrimp meats in all seasons of the year. To solve these problems, ready-to-use soup mixtures are often served in restaurants as well as homes. However, these soups are not entirely satisfactory since their flavor is not interesting for the majority of Iranians. Hence, soup powders sold in Iranian markets are often prepared from red meat and chicken (3). Macrobrachium nipponense is a tiny shrimp that its population has recently been increased in Anzali Lagoon (north of Iran, Gilan Province) as well as many freshwaters of the world, especially East Asian rivers. The shrimp is a member of Palaemonida family. This decapod crustacean is one of the most 
important native shrimps in China, Korea and Japan $(4,5,6)$. Presence of non-native $M$. nipponense in Iran rivers has been first reported by De Grave and Ghane (7). It is hypothesized that this shrimp has been introduced randomly or through fish transmission from their natural habitats such as China to Iran waters (6). Summer is the best season for the shrimp natural reproduction (8). Drying under sunshine is still a common method for the meat treatment in most of developing countries due to the low cost. However, this method cannot be used on cloudy days. Furthermore, this method can significantly reduce the quality of dried shrimps since they may be contaminated with dusts and insects. Teeboonma et al. (9) reported that the damage occured by insects, animals and weather was nearly $30-40 \%$. Therefore, other methods must be used for drying shrimps. Namsanguan et al. (10) reported that features such as red-orange color and low shrinkage were preferred qualities in dried shrimps. The cabinet-type air dryer is one of the methods used to dry tiny shrimps under controlled conditions because this type of dryers includes sensors that control humidity and relative vacuum. Moreover, they are easily set up for each sample by the operator. Relatively, use of metalized polyethylene films can be helpful to increase the product shelf life. In fact, metalized polyethylene films are polymer films coated with a thin layer of metals, usually aluminum, and a thick layer of polyethylene. They are widely used for decorative and food packaging purposes. The vacuum packaging is an appropriate technic to prevent destructive microorganisms. Therefore, the aim of this study was to produce dried shrimp meats with high quality to using acuum packaging with metalized polyethylene films. Furthermore, meat chemicals such as thiobarbituric acid (TBA), peroxide value (PV), total volatile base nitrogen (TVB-N) and free fatty acid (FFA) were assessed to calculate meat shelf life at room temperature. Sensory evaluation and microbial characteristic investigation were carried out during 6 months of storage.

\section{Materials and Methods}

Chemicals: Chemicals and media such as chlorideic acid, methanol, hexane, potassium chromate, acetic acid, potassium chromate, sodium sulfate, boric acid, sodium thiosulphate, potassium iodide, starch, silver nitrate, sulfuric acid, methyl red, TBA, yeast glucose chloramphenicol agar and plate count agar were purchased from Sigma (USA) and Merck (Germany). All consumable chemicals were high in purity.
Preparation of dried shrimp meat powder: Totally, $40 \mathrm{~kg}$ of $M$. nipponense tiny shrimps were harvested from Anzali Lagoon (Gilan Province, Iran) from 25 June to 20 August, 2016. Shrimp samples were washed with cold tap water $\left(3{ }^{\circ} \mathrm{C}\right)$ to remove dust, sand and other potential contaminants. Then, cleaned samples were dipped in $\mathrm{NaCl}$ solution $(10 \% \mathrm{w} / \mathrm{v})$ with 1:2 ratios at boiling temperature for $3 \mathrm{~min}$. After spreading the samples on mesh trays to remove the excess water, samples were cooled for $10 \mathrm{~min}$ and then dried using a cabinet-type air dryer (Osaw Industrial Products Pvt. Ltd, India) at $70{ }^{\circ} \mathrm{C}$ for $6 \mathrm{~h}$. The moisture content of the samples was less than $10 \%$. Boiled samples with initial moisture contents of 270-350\% were thin-layer dried using hot airs of 40$90{ }^{\circ} \mathrm{C}$ with an inlet air-flow rate of $1.0 \pm 0.2 \mathrm{~m} / \mathrm{s}$. The inlet drying air temperature was controlled by a proportional-integral derivative (PID) controller with an accuracy of $\pm 1{ }^{\circ} \mathrm{C}$. During the drying time, Samples were weighed continuously using electric balance (A\&D model GF3000, Japan) with $\pm 0.1 \mathrm{~g}$ accuracy. Dried samples were ground using grinder (Cuisinart SG-10 Electric Grinder. USA) after removal of the shrimp shell, head and tail.

Preparation of uncooked semi ready-to-eat soup powders: The grounded shrimp meats used in soup preparation are shown in Table 1. Ingredients were perfectly mixed. After preparing the soup formulation, each $100 \mathrm{~g}$ of the preparations was packed in a vacuum metalized polyethylene film. These were stored at room temperature for 6 months. Each month, three packages were randomly selected and tested. Chemical preservatives were not used in this study.

Table 1. A new formulation of semi ready-to-eat soup powders

\begin{tabular}{ll}
\hline Formulation & \% \\
\hline Dry shrimp powder & 4 \\
Onion & 5 \\
Garlic & 3 \\
Solid vegetable oil & 10 \\
Milk powder & 25 \\
White pepper & 0.1 \\
Parsley powder & 1 \\
Peppermint powder & 1 \\
Wheat flour & 35 \\
Potato flour & 10 \\
Cornstarch & 2 \\
Turmeric & 0.6 \\
Granular carrot & 0.5 \\
Salt & 2.8 \\
\hline Total & 100 \\
\hline
\end{tabular}


Preparation of cooked semi ready-to-eat soup powders: Briefly, $100 \mathrm{~g}$ of the soup powder were dissolved in four glasses of cold water. After complete dissolving, the solution was warmed using gentle flame for $20 \mathrm{~min}$ to achieve an internal temperature of nearly $80{ }^{\circ} \mathrm{C}$.

Fatty acid compositions of dried shrimp meats: The FA compositions of dried shrimp powders were assessed based on a protocol by Castro et al. (11). Briefly, $0.075 \mathrm{~g}$ of the sample was dissolved in $1 \mathrm{ml}$ of toluene and $2 \mathrm{ml}$ of $1 \% \mathrm{H}_{2} \mathrm{SO}_{4}$ in methanol. After extracting the esters using $5 \mathrm{ml}$ of hexane, organic layers were separated and washed with $4 \mathrm{ml}$ of $2 \%$ $\mathrm{KHCO}_{3}$. Mixture was dried using anhydrous $\mathrm{Na}_{2} \mathrm{SO}_{4}$ and filtered. After removing the organic solvent, the fatty acid methyl ester (FAME) was subjected to gas chromatography [GC Agilent Technologies, $6890 \mathrm{~N}$ system, USA]. The initial temperature was $70^{\circ} \mathrm{C}$ and then increased to $250{ }^{\circ} \mathrm{C}$. The injection temperature was $220{ }^{\circ} \mathrm{C}$. Helium was used as the carrier gas at a flow rate of $1 \mu \mathrm{l} / \mathrm{min}$.

Proximate compositions of dried shrimp meats: Total protein contents of dried shrimp meats were calculated based on the nitrogen contents, analyzed using micro-Kjeldahl system (Techno Service Co, Behr, K 24, Germany). Nitrogen quantity was calculated by multiplying in a factor of 6.25 (12). Crude lipid contents were extracted from dried shrimp meats using Soxhlet extractor (Behr, Labor-Technik, Germany) and petroleum ether as solvent. Extracts were oven-dried at $105{ }^{\circ} \mathrm{C}$ overnight and then weighted (12). Ash contents of dried shrimp meats were estimated by heating the samples at $525{ }^{\circ} \mathrm{C}$ for $16 \mathrm{~h}$ using furnace (Muffle Furnace, SEF-202, Korea) (12). Residual moisture contents of the samples were calculated using oven drying at $105{ }^{\circ} \mathrm{C}$ to a constant weight (12). Carbohydrate and calorie contents of the shrimp meats were reported based on the methods by AOAC (12). To estimate the quantity of salts in dry shrimp meats, $5 \mathrm{~g}$ of the sample were weighted in a crucible and then converted to ash at $550{ }^{\circ} \mathrm{C}$ in a furnace (Muffle Furnace, SEF-202, Korea) until a constant mass was achieved. This was cooled down and transferred to a volumetric flask. The volume was adjusted to $100 \mathrm{ml}$ using distilled water (D.W.) and filtered using Whatman No. 1 filter papers. Twenty milliliters of the filtered was titrated with $0.1 \mathrm{~N}$ of silver nitrate solution using a few drops of $10 \%$ potassium chromate as indicator. The proportion of salt was calculated as follows $(13,14,15)$ :

$$
\text { Salt }_{\text {Value }}=\frac{\text { Volume }(\mathrm{ml}) \text { of silver nitrate } \times 0.005845 \times 100}{\text { Sample mass }(\mathrm{g})}
$$

Proximate compositions of uncooked semi readyto-eat soup powders: Proximate compositions (protein, lipid, ash, moisture, carbohydrate and calorie) of the soup powder were analyzed based on methods by AOAC (12) described in Section of proximate compositions of dried shrimp meats.

Assessment of the shrimp meat shelf life: The following experiments were carried out to calculate shelf life of the samples during 6 months of storage at room temperature.

Calculation of water activity $\left(\mathbf{a}_{\mathbf{w}}\right)$ : Water activity $\left(a_{w}\right)$ of uncooked semi ready-to-eat soup powders was calculated using decagon water activity meter (Aqua Lab Series 3, Decagon Devices, USA). Briefly, $\mathrm{a}_{\mathrm{w}}$ of $2 \mathrm{~g}$ of the sample was automatically calculated by the instrument. The ratio of water vapor pressure in samples to pure water vapor pressureis $\mathrm{a}_{\mathrm{w}}$ content (16).

\section{Chemical analyses}

Assessment of thiobarbituric acid (TBA): The TBA of the samples was assessed using the steam distillation method (17). Based on the method, $10 \mathrm{~g}$ of the soup powder were mixed with $97.5 \mathrm{ml}$ of D.W. and shaked by hand for $2 \mathrm{~min}$. While shaking, $2.5 \mathrm{ml}$ of $4 \mathrm{~N} \mathrm{HCl}$ were added to the mixture. Then, antibumping and antifoam granules were added to the mixture. Mixture was heated until $50 \mathrm{ml}$ of distilled solution were achieved. The TBA of soup powder was repoted as $\mathrm{mg}$ of malondialdehyde per $\mathrm{kg}$ of sample. This was calculated using the following formula:

$\mathrm{TBA}_{\text {Value }}=7.8 \times \mathrm{Abs}_{538}$

Assessment of peroxide value (PV): The PV of the samples was assessed using methods by AOAC (12). The value was reported as milli-equivalents of oxygen per $1000 \mathrm{~g}$ of oil. Briefly, $50 \mathrm{~g}$ of the soup powders were weighed in a ground glass. Then, $100 \mathrm{ml}$ of chloroform were added to the powder and mixed well. The mixture was stored in a dark room for $2 \mathrm{~h}$ and then filtered. Filtered solutions $(25 \mathrm{ml})$ were transferred into a glass jar undera fume hood to evaporate the solvent. After evaporating, the fat in the 
container was weighed. The remaining solution was added to $37 \mathrm{ml}$ of acetic acid, $30 \mathrm{ml}$ of D.W., $1 \mathrm{ml}$ of potassium iodide and $1 \mathrm{ml}$ of starch solution. The mixture was gently swirled and titrated using $0.01 \mathrm{~N}$ of $\mathrm{Na}_{2} \mathrm{~S}_{2} \mathrm{O}_{3}$. The PV was calculated using the following formula:

$$
\mathrm{PV}_{\text {Value }} \frac{\mathrm{V}_{2} \times \mathrm{N} \times 1000}{\mathrm{~W}}
$$

When V2 was volume of sodium thiosulfate for titration, $\mathrm{N}$ was normality of sodium thiosulfate and $\mathrm{W}$ was weight of lipid in gram.

Assessment of total volatile base nitrogen (TVB$\mathbf{N})$ : The TVB-N of the samples was assessed based on a protocol by Woyewoda et al. (18). Briefly, $300 \mathrm{ml}$ of D.W. and $10 \mathrm{~g}$ of the soup powders were added to a round bottom distillation flask and shaked by hand. Then, $2 \mathrm{~g}$ of magnesium oxide and anti-bumping granules were added to the flask. Twenty-five milliliters of $2 \%$ boric acid and a few drops of the indicator $(1 \mathrm{~g}$ of phenolphthalein in $100 \mathrm{ml}$ of $95 \%$ ethanol) were added to aglass flask. The distilling flask was heated to boil the liquid for exactly $10 \mathrm{~min}$. The solutions were reheated and distilled for exactly $25 \mathrm{~min}$. After the distillation, solutions were collected in receiver flasks and titrated to a purple endpoint of $0.1 \mathrm{~N} \mathrm{H}_{2} \mathrm{SO}_{4}$. The TVB-N was reported as $\mathrm{mg}$ of nitrogen per $100 \mathrm{~g}$ of sample using the following formula:

$$
\mathrm{TVB}-\mathrm{N}_{\text {Value }}=\frac{\text { volume }(\mathrm{ml}) \text { of sulfuric acid } \times \mathrm{N} \times 100 \times 14}{\text { Sample }(\mathrm{g})}
$$

Assessment of free fatty acid (FFA): In general, 10 $\mathrm{g}$ of the soup powders, $50 \mathrm{ml}$ of methanol and $50 \mathrm{ml}$ of chloroform were added to a small blender jar and mixed for $1 \mathrm{~min}$. This was filtered using Whatman No. 4 filter papers and rinsed with a small amount of chloroform in a flask. Then, $45 \mathrm{ml}$ of D.W. were added to the filtrate to achieve a final chloroform/methanol/water ratio of 1:1:1 $(\mathrm{v} / \mathrm{v} / \mathrm{v})$. the jar was swirled gently and the contents were transferred to a $250-\mathrm{ml}$ separatory funnel. Flask was rinsed with chloroform and washings were added to a separatory funnel and left overnight at room temperature. After equilibrium, the lower chloroform layer was slowly filtered using a double $15-\mathrm{cm}$ filter paper (Whatman No. 1 outter and Whatman No. 4 inner), half filled with anhydrous sodium sulfate, and rinsed with chloroform. Ten milliliters of the chloroform filtrate were transferred into pre-weighed aluminum drying dishes and allowed to evaporate the solvent. After evaporating, Dishes were heated in an oven at $103{ }^{\circ} \mathrm{C}$ for 1 hand then were cooled down and weighed. The remaining volumetric solution was transferred to a 250-ml flask and rinsed with $10 \mathrm{ml}$ of chloroform. Solution was added with $70 \mathrm{ml}$ of 2propanol, $35 \mathrm{ml}$ of methanol and eight drops of metacresol purple indicator and mixed well. This was titrated to violet endpoint of $0.05 \mathrm{~N} \mathrm{NaOH}$. The FFA was reported as percentage of oleic acid $(14,18)$.

Color assessment: The colorimeter (NR60CP Precision Colorimeter, 3nh, China) was used for measuring the color parameters such as $\mathrm{L}^{*}$ (lightness), $\mathrm{a}^{*}$ (redness) and $\mathrm{b}^{*}$ (yellowness).

Sensory assessment: The sensory assessment was carried out using a method by Meilgaard (19). Sensory scores were calculated based on a 5-point system per sample to assign values for the statistical analysis. At the beginning of the test, 100 individuals of panel members were chosen. These individuals rinsed their mouth with water and then tasted the prototype samples. Scores included 0, very bad; 1 , bad; 2, medium; 3, good; 4, very good and 5, excellent.

Microbial analysis: The microbial analysis was performed using pour plate method. Briefly, $45 \mathrm{ml}$ of peptone water were bended with $5 \mathrm{~g}$ of the sample at various dilutions. One milliliter of this blend was transferred into the sterile plates. Plate count agar and yeast glucose chloramphenicol agar culture media were pre-sterilized. Generally, 15-20 $\mathrm{ml}$ of the media was added to each plate. Plates were thoroughly mixed using rotational movement. Plates were incubated at $37{ }^{\circ} \mathrm{C}$ for two days (bacteria) and at $23{ }^{\circ} \mathrm{C}$ for five days (molds and yeasts) (ISIRI, 2007). Colonies were counted using the following formula:

$$
\mathrm{N}_{\text {Value }}=\frac{\mathrm{c}}{V\left(\mathrm{n}_{1}+0.1 \mathrm{n}_{2}\right) d}
$$

$\mathrm{N}$ : number of microorganisms; c: total number of colonies counted in all plates selected from two consecutive ranges; $\mathrm{V}$, inoculated volume per plate $(\mathrm{ml}) ; \mathrm{n}_{1}$, number of plates counted at the first dilution; $\mathrm{n}_{2}$, number of plates counted at the second dilution; $\mathrm{d}$, dilution coefficient was selected based on the first dilution.

Statistical analysis: The statistical analysis was carried out using SAS software (Version 9.4, SAS Institute Inc., Cary, NC, USA). Duncan's Multiple 
Range and LSD tests $(P=0.05)$ were used to show significance of differences between the specific means. Data were reported as mean \pm standard deviation (SD). All examinations were carried out in triplicate.

\section{Results}

Assessment of fatty acid compositions: The main FAcompositions of dried shrimp meat powders were shown in Table 2. Compositions consisted of $\Sigma$ SFA, $33.36 \pm 2.5 \%$; $\Sigma$ MUFA, $21 \pm 1.6 \%$ and $\Sigma$ PUFA, 38.92 $\pm 2.1 \%$.

Table 2. Fatty acid compositions of dried shrimp meat powders using cabinet-type air dryer

\begin{tabular}{lll}
\hline & Fatty acid composition & Value (\%) \\
\cline { 3 - 3 } & & Dried shrimp meat \\
\hline \multirow{4}{*}{ SFA $14: 0$} & C16:0 & $0.31 \pm 0.01$ \\
& C18:0 & $18.49 \pm 0.14$ \\
& C20:0 & $13.02 \pm 0.01$ \\
& C22:0 & $0.41 \pm 0.01$ \\
& & $1.13 \pm 0.01$ \\
MUFA & C16:1 $18: 1, n-9$ & $1.13 \pm 0.01$ \\
& C20:1 & $19.28 \pm 0.01$ \\
& & $0.59 \pm 0.01$ \\
PUFA & C18:2 $18: 3, n-3$ & \\
& C20:5, n-3 (EPA) & $19.67 \pm 0.01$ \\
& C22:6, n-3 (DHA) & $8.69 \pm 0.01$ \\
\hline
\end{tabular}

Results are expressed as Mean \pm SD $(n=3)$; SFA, saturated fatty acids; MUFA, monounsaturated fatty acids; PUFA, polyunsaturated fatty acids; C, carbon; $n$, Number; EPA, eicosapentaenoic acid; DHA, docosahexaenoic acid

Assessment of proximate compositions: Results of proximate compositions of dried shrimp and semiready-to-eat soup powders are presented in Table 3. The protein content in dried shrimp was high (72.74 $\pm 1.99 \%$ ). The protein content in prepared soup powders was nearly $10 \%$ higher than that in other samples in the market (nearly 6\%). However, fat, ash, moisture, salt and carbohydrate contents in dried shrimp meats were similar to those in other samples in the market. The fat, ash, moisture and salt contents in dried samples of shrimps respectively included $3.03 \pm 0.75 \%, 9.33 \pm 0.00 \%, 6.32 \pm 0.07 \%$ and 3.49 $\pm 0.07 \%$ of the dry weight. The calorie of dried shrimps included $0.4 \mathrm{kj}$ (95 cal.). This included $313.97 \mathrm{kj}$ per 100 grams of sample in soup.

Table 3. Proximate compositions of dried shrimp meats and uncooked semi ready-to-eat soup powders

\begin{tabular}{lcc}
\hline Composition & Dried shrimp meat & Soup powder \\
\hline Protein & $72.74 \pm 1.99 \%$ & $10.00 \pm 0.01 \%$ \\
Fat & $3.03 \pm 0.75 \%$ & $14.33 \pm 0.01 \%$ \\
Moisture & $6.32 \pm 0.07 \%$ & $7.81 \pm 0.18 \%$ \\
Ash & $9.33 \pm 0.00 \%$ & $4.97 \pm 0.59 \%$ \\
Salt & $3.49 \pm 0.07 \%$ & $3.00 \pm 0.01 \%$ \\
Carbohydrate & - & $36.25 \pm 0.01 \%$ \\
Calorie & $0 / 4 \pm 0.02 \mathrm{kj} / 100 \mathrm{~g}$ & $313.97 \pm 0.25 \mathrm{kj} / 100 \mathrm{~g}$ \\
\hline \multicolumn{2}{l}{ Results are expressed as Mean $\pm \mathrm{SD}(n=3)$}
\end{tabular}

Assessment of water activity $\left(a_{w}\right)$ during storage: Results of $a_{w}$ in soup powders are shown in Table 4. The $\mathrm{a}_{\mathrm{w}}$ increased with increased storage time at room temperature. a statistically significant difference was seen from the Month 4 to Month $6(P<0.05)$.

Chemical analysis of samples during storage: Spoilage indicators such as TBA, PV, TVB-N and FFA were analysed during the storage. Results of the TBA analysis for the soup powders packaged in metalized polyethylene films during storage at room temperature are demonstrated in Table 4. The TBA content of the samples was significantly affected by the storage time $(P<0.05)$. The TBA content in soup powders gradually increased during storage at room temperature. Results of peroxide value changes in soup powders during six months of storage at room temperature indicated that the PV increased with increased storage time $(P<0.05)$. Table 4 shows that TVB-N value included $13.30 \mathrm{mg} \mathrm{N} / 100 \mathrm{~g}$ of sample in soup powders in the first month, and $20.30 \mathrm{mg}$ $\mathrm{N} / 100 \mathrm{~g}$ of sample after six months of storage. A significant difference $(P<0.05)$ was seen between the Month 1 and Month 6 of storage. Results of FFA (percentage of oleic acid) content assessment showed that FFA slightly increased from an initial value of 0.27 to $9.69 \%$ of oleic acid during six months of storage at room temperature.

Color and sensory analyses of the samples during storage: Table 4 shows results for the assessment of of color values $\left(\mathrm{L}^{*}, \mathrm{a}^{*}\right.$ and $\left.\mathrm{b}^{*}\right)$ in uncooked and cooked soup powders. As the storage time increased, $\mathrm{L}^{*}$ value increased in cooked soup powders while $\mathrm{a}^{*}$ and $b^{*}$ values decreased. Therefore, the storage time was significant $(P<0.05)$ on $\mathrm{L}^{*}, \mathrm{a}^{*}$ and $\mathrm{b}^{*}$ values. Figure 1 demonstrates results of the sensory assessment (color, odor, flavor/taste and texture) of the soup powders by the panel members. Sensory evaluation values in the first month were significantly higher than those in the end of storage $(P<0.05)$. 

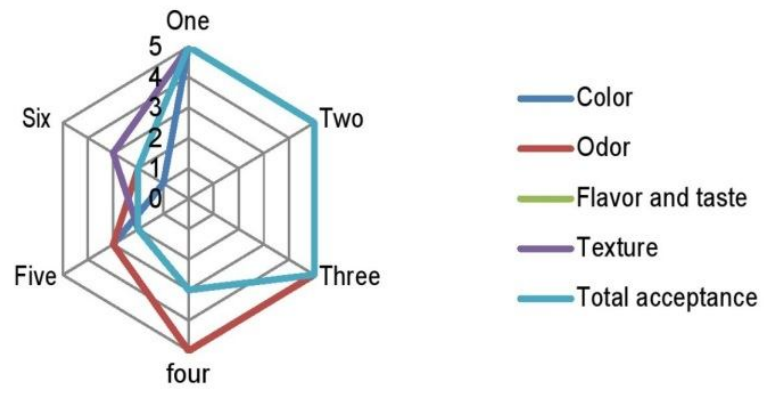

Fig 1. Sensory analysis of cooked semi ready-to-eat soup powders during 6 months of storage at room temperature

\section{Microbial analysis of samples during storage: For} the microbial analysis, three packs of the soup powders were randomly chosen (Table 5). The count of total bacteria and mold and yeast contents in soup powders included 4.1 and $3.79 \mathrm{cfu} / \mathrm{g}$ of sample during 6 months of storage. Therefore, the microorganism counts increased during the storage. The lowest numbers of bacteria and fungi (molds and yeasts) were recorded in Month 1 with 1.2 and $1.4 \mathrm{cfu} / \mathrm{g}$ of sample and the highest numbers recorded in Month 6 with 4.1 and $3.79 \mathrm{cfu} / \mathrm{g}$ of sample.

\section{Disc ussion}

The PUFA content is reported to decrease during drying in fish species (20). In fact, the lipid content in shrimps is mainly formed by phospholipids (72-74\%) and triacylglycerols (16\%). However, PUFA are mostly esterified to phospholipids rather than triacylglycerols (21). Marine phospholipids are more resistant to oxidation than bulk fish oil (mostly triacylglycerols) from the same sources are (22). This could explain the insignificant changes observed in the content of EPA and DHA during the drying process of shrimps.

Table 4. Water activity, chemical analysis and color change of uncooked and cooked semi ready-to-eat soup powders during 6 months of storage at room temperature

\begin{tabular}{|c|c|c|c|c|c|c|c|}
\hline \multirow[t]{2}{*}{ Chemical analysis } & \multirow[t]{2}{*}{ Soup powder } & \multicolumn{5}{|c|}{$\begin{array}{l}\text { Storage time } \\
\text { (month) }\end{array}$} & \multirow[b]{2}{*}{6} \\
\hline & & 1 & 2 & 3 & 4 & 5 & \\
\hline $\mathrm{a}_{\mathrm{w}} \%$ & Uncooked & $0.30 \pm 0.01^{\mathrm{a}}$ & $0.30 \pm 0.01^{\mathrm{a}}$ & $0.32 \pm 0.01^{\mathrm{a}}$ & $0.35 \pm 0.02^{\mathrm{ab}}$ & $0.37 \pm 0.02^{b}$ & $0.45 \pm 0.03^{\mathrm{c}}$ \\
\hline $\begin{array}{l}\text { TBA (mg malondialdehyde } \\
\text { /kg sample) }\end{array}$ & Uncooked & $0.16 \pm 0.02^{\mathrm{d}}$ & $0.57 \pm 0.00^{c}$ & $0.88 \pm 0.00^{\mathrm{b}}$ & $0.89 \pm 0.01^{\mathrm{b}}$ & $1.00 \pm 0.00^{\mathrm{a}}$ & $1.22 \pm 0.00^{\mathrm{a}}$ \\
\hline PV (meq/kg lipid) & Uncooked & $0.09 \pm 0.00^{\mathrm{d}}$ & $0.14 \pm 0.00^{\mathrm{d}}$ & $0.65 \pm 0.00^{c}$ & $1.65 \pm 0.00^{\mathrm{b}}$ & $1.69 \pm 0.00^{\mathrm{b}}$ & $3.14 \pm 0.00^{\mathrm{a}}$ \\
\hline TVN (mgN/100 g of sample) & Uncooked & $13.30 \pm 0.07^{\mathrm{c}}$ & $13.29 \pm 0.07^{\mathrm{bc}}$ & $16.25 \pm 0.00^{\mathrm{b}}$ & $16.80 \pm 1.40^{\mathrm{ab}}$ & $18.90 \pm 0.70^{\mathrm{a}}$ & $20.30 \pm 4.20^{\mathrm{a}}$ \\
\hline FFA ( $\%$ of oleic acid) & Uncooked & $0.27 \pm 0.01^{\mathrm{d}}$ & $3.16 \pm 0.39^{c}$ & $3.25 \pm 0.68^{\mathrm{c}}$ & $7.16 \pm 0.73^{\mathrm{b}}$ & $8.10 \pm 0.75^{\mathrm{a}}$ & $9.69 \pm 0.38^{\mathrm{a}}$ \\
\hline $\mathrm{L}^{*}$ & $\begin{array}{l}\text { Uncooked } \\
\text { Cooked }\end{array}$ & $\begin{array}{l}82.69 \pm 0.96^{\mathrm{a}} \\
61.20 \pm 0.16^{\mathrm{f}}\end{array}$ & $\begin{array}{l}84.18 \pm 0.19^{\mathrm{a}} \\
64.15 \pm 0.14^{\mathrm{e}}\end{array}$ & $\begin{array}{l}75.00 \pm 0.18^{\mathrm{b}} \\
66.50 \pm 0.11^{\mathrm{d}}\end{array}$ & $\begin{array}{l}77.14 \pm 0.12^{\mathrm{c}} \\
68.24 \pm 0.22^{\mathrm{c}}\end{array}$ & $\begin{array}{c}77.50 \pm 0.21^{\mathrm{c}} \\
74.30 \pm 0.2^{\mathrm{b}}\end{array}$ & $\begin{array}{l}77.23 \pm 0.31^{\mathrm{c}} \\
82.07 \pm 0.45^{\mathrm{a}}\end{array}$ \\
\hline$a^{*}$ & $\begin{array}{l}\text { Uncooked } \\
\text { Cooked }\end{array}$ & $\begin{array}{l}2.71 \pm 0.88^{\mathrm{c}} \\
4.00 \pm 0.01^{\mathrm{a}}\end{array}$ & $\begin{array}{l}3.31 \pm 0.47^{\mathrm{bc}} \\
3.37 \pm 0.00^{\mathrm{ab}}\end{array}$ & $\begin{array}{l}3.58 \pm 0.03^{b} \\
3.18 \pm 0.03^{b}\end{array}$ & $\begin{array}{l}4.38 \pm 0.23^{\mathrm{b}} \\
2.38 \pm 0.03^{\mathrm{c}}\end{array}$ & $\begin{array}{l}4.38 \pm 0.21^{\mathrm{b}} \\
2.35 \pm 0.01^{\mathrm{c}}\end{array}$ & $\begin{array}{l}5.87 \pm 0.19^{\mathrm{a}} \\
2.45 \pm 0.01^{\mathrm{c}}\end{array}$ \\
\hline$b^{*}$ & $\begin{array}{l}\text { Uncooked } \\
\text { Cooked }\end{array}$ & $\begin{array}{l}37.29 \pm 0.73^{\mathrm{b}} \\
55.26 \pm 0.23^{\mathrm{a}}\end{array}$ & $\begin{array}{l}42.96 \pm 0.94^{\mathrm{a}} \\
52.16 \pm 0.14^{\mathrm{a}}\end{array}$ & $\begin{array}{l}40.52 \pm 0.15^{\mathrm{a}} \\
52.12 \pm 0.05^{\mathrm{a}}\end{array}$ & $\begin{array}{l}38.62 \pm 0.08^{b} \\
46.78 \pm 0.09^{b}\end{array}$ & $\begin{array}{l}38.30 \pm 0.21^{\mathrm{b}} \\
40.50 \pm 0.01^{\mathrm{c}}\end{array}$ & $\begin{array}{l}38.58 \pm 0.61^{\mathrm{b}} \\
39.42 \pm 0.04^{\mathrm{c}}\end{array}$ \\
\hline
\end{tabular}

The lowercase letters in each row indicate significant differences $(P<0.05)$; results are expressed as Mean $\pm \mathrm{SD}(n=3)$; $\mathrm{a}_{\mathrm{w}}$, water activity; TBA, thiobarbituric acid; PV, peroxide value; TVN, total volatile nitrogen; FFA, free fatty acid; $L^{*}$, lightness, $a^{*} ;$ redness; $b^{*}$, yellowness

Table 5. Microorganism counts of uncooked semi ready-to-eat soup powders during 6 months of storage at room temperature

\begin{tabular}{lccccccc}
\hline $\begin{array}{l}\text { Microorganism count } \\
\text { (cfu/g of sample) }\end{array}$ & \multicolumn{5}{c}{ Storage time (month) } \\
\hline \multirow{2}{*}{ Soup powder } & Total bacteria & $1.4 \pm 0.00^{\mathrm{d}}$ & $2.8 \pm 0.00^{\mathrm{c}}$ & $2.8 \pm 0.01^{\mathrm{c}}$ & $3.5 \pm 0.01^{\mathrm{b}}$ & $3.2 \pm 0.02^{\mathrm{b}}$ & $4.1 \pm 0.01^{\mathrm{a}}$ \\
& & & & & & & \\
& Mold and yeast & $1.2 \pm 0.00^{\mathrm{c}}$ & $2.7 \pm 0.00^{\mathrm{b}}$ & $2.7 \pm 0.01^{\mathrm{b}}$ & $2.7 \pm 0.01^{\mathrm{b}}$ & $2.1 \pm 0.02^{\mathrm{b}}$ & $3.79 \pm 0.01^{\mathrm{a}}$ \\
\hline
\end{tabular}

The lowercase letters in each row indicate significant differences $(P<0.05)$; results are expressed as Mean $\pm \mathrm{SD}(n=3)$ 
Sampaio et al. (23) compared FA profile of the dried shrimp species in various seasons (summer, autumn and winter). They reported that shrimps contained a total of SFA of $27.49 \%$, MUFA of $43.73 \%$, PUFA of $28.79 \%$ and EPA and DHA of $19.96 \%$. Therefore, Results of this study and other studies indicated that dried shrimp meats included sufficient contents of FAs, which are necessary to prevent many diseases. Dried shrimp meats are rich sources of protein and can be used as healthy foods. Based on the results, protein contents in dried shrimp meats were high $(72.74 \pm 1.99 \%$ of dry weight $)$. Akonor et al. (24) studies on marine shrimp of Penaeus notialis showed that protein contents in airoven-dried (85.64 $\pm 0.26 \%)$ and solar-dried (84.89 $\pm 0.51 \%$ ) shrimps were high. Differences in protein contents of dried shrimps might be attributed to differences in species, growth stages and seasons. Shrimp fats are mainly consist of polyunsaturated FAs (24). Fat contents in this study were lower than the fat contents of studies by Akonor et al. (24) and Wu and Mao (25) on dried shrimps of $P$. notialis and grass carp (Ctenopharyngodon idellus) dried fillets, respectively. Ash is the remaining minerals in foods. The ash contents of dried samples in the present study were higher than the ash contents in studies by $\mathrm{Wu}$ and Mao (25) and Akonor et al. (24). For the moisture, Kamalakar et al. (26) reported that drying characteristics of prawn and fish meats showed that increased drying temperature and time decreased primary moisture of the samples. Therefore, moisture contents less than $10 \%$ included further effective roles in sample shelf life. In the current study, salt adsorption was assessed after processing of dried shrimp meats. Niamnuy et al. (13) studies on quality changes of shrimp meats during boiling in salt solutions showed that the salt absorption in shrimp meats increased with increased boiling time (min). After adding shrimp meats to other soup ingredients, the proximate composition results of soup powders proved the nutritious values for the consumers.

Ensure of safety and food quality during production and storage processes is a major challenge. One of the critical factors to be continuously measured and controlled in production, distribution and storage of foods is $\mathrm{w}_{\mathrm{a}}$. In this study, $\mathrm{w}_{\mathrm{a}}$ increased with increased storage time at room temperature. This increase in $\mathrm{w}_{\mathrm{a}}$ could occur due to bacterial growth in soup powders. Modi et al. (27) reported $\mathrm{w}_{\mathrm{a}}$ of dehydrated chicken kebabs $0.31-0.42 \%$ during 6 months of storage. Therefore, effects of time on soup powders are significant during storage at room temperature. The TBA index shows the secondary oxidation products, especially aldehydes (28). The presence of such compounds results in changes in sensory characteristics, including flavor and odor. Analysis of TBA showed that soup powders with higher TBA values showed further lipid oxidation after 4 months of storage at room temperature. In 2008, the National Iranian Standards Organization (IRI) has suggested the maximum 1-2 $\mathrm{mg}$ of malondialdehyde/ $\mathrm{kg}$ of sample as an acceptable limit in soup powders (29). Hence, Month 4 was the last month of storage in this study.

The PV indicates the total quantity of hydroperoxides (the initial product of oxidative changes). It is one of the most widely used indicators for oxidative rancidity in oils and fats (1). The PV of soup powders in Months 5 and 6 of the storage showed further changes. This was similar to results by Xue-Yan et al. (30) on effects of processing conditions on nutritional values of fish soups. The TVB-N is an indicator of the freshness analysis in food products (31). This indicator includes a widerange of volatile compounds such as ammonia, methylamine, dimethylamine and trimethylamine (32). Large quantities of TVB-N can result in enzyme activity, proteolysis and protein degradation (33). Hence, increases in TVB-N during the storage can be attributed to spoilage activitiesy of bacteria. High activities of such bacteria break down compounds such as trimethylamine oxide, peptides and amino acids into volatile species (34). The TVB-N values increase during storage and the spoilage limit includes 25-30 mg N/100 g of sample $(35,36)$. In 2005, Mol (36) studied shelf life of ready-to-eat fish soups and reported TVB-N from 5.26 in the first and more than $10 \mathrm{mg} \mathrm{N} / 100 \mathrm{~g}$ after 15 weeks of storage. Chacko et al. (37) recorded the TVB-N in squid soups as 7.20 in the first day to more than $21 \mathrm{mg} \mathrm{N} / 100 \mathrm{~g}$ after five months of storage; similar to those from the current study.

The FFA is a quality index in foods. In this study, Month 4 was the beginning of the most changes in FAs of the soup powders as the quality decreased. Chacko et al. (37) studies on the shelf-life of soup powders from squid Sepioteuthis lessoniana showed that the FFA increased slowly during the storage. In 
general, increases in FAs indicate decreases in quality of the products. One of the reasons for increasing FAs in this product can be due to the vegetable oils added to the soup formulation. The first and most important quality features of foods for the consumers include appearance and color. Therefore, color affects the consumer acceptance. In this study, increase in $\mathrm{L}^{*}$ parameter could be due to decrease in quality of soup powders during storage at room temperature. However, the most important criterion of the food quality for the consumers is sensory evaluation because peoples really care about the good sense of eating pleasure. Results of sensory evaluations showed that color and odor indices in cooked soup powders included the best grade (Grade 5) by trained panel members during 4 months of storage. Flavor and taste of cooked soup powders were good as well. Hence, most panel members enjoyed the soup until the end of Month 6. Results of this study were similar to studies by Chacko et al. (37) on soup powders prepared from squids and those by Mol (36) on readyto-eat fish soups. In total, the sensory quality of cooked soup powders was excellent (Grade 5) at the beginning but descended during the storage. The value was lower than two in Month 5 of storage. As a result, samples were not accepted for the consumption after this time. Fish contain suitable compounds for the growth of microorganisms. Therefore, presence of bacteria is one of the reasons for decreased quality of fish during the storage (38). Indeed, primary microbial contamination, storage status and packaging play important roles in shelf life of fishery products (39). The maximum suggested limit for TVC in fish is 7 (40). Microbial results from the present study were similar to results from Mol (36) studies on fish soups. In the present study, number of microorganisms increased with increased storage time. However, this increase was in a satisfactory range. This could occur due to the gradual increase in $w_{a}$ of soup powders. Generally, the best time for use of soup powders in terms of quality and microbial loads included Months 1 to 4 .

\section{Conclusion}

In general, soup powders prepared using $4 \%$ dried shrimp ( $M$. nipponense) meats were excellent in taste with high nutritional values. Furthermore, the spoilage indicators such as TBA, PV, TVB-N and FFA were analyzed during six months of storage at room temperature. Results showed that the soup powder chemical analysis seen acceptable for consumption until Month 6. However, the sensory analysis was acceptable until Month 4. Until this month, the sensory score was acceptable and no significant changes in color, odor, flavor and other characteristics were observed.

\section{Financial disclosure}

The authors declaire no conflict of interest regarding the publication.

\section{Funding/Support}

This research project was financially supported by Inland Waters Aquaculture Research Center, Iranian Fisheries Science Research Institute, Agricultural Research, Education and Extension Organization, Bandar Anzali, Iran.

\section{References}

1. Haghshenas $M$, Hosseini $H$, Nayebzadeh $K$, Shabkoohi Kakesh B, Mahmoudzadeh M, Komeyli Fonood R. Effect of beta glucan and carboxymethyl cellulose on lipid oxidation and fatty acid composition of pre-cooked shrimp nugget during storage. LWT - Food Sci Tech. 2015;62:242-248.

2. Chotimarkorn C, Benjakul S, Silalai N. Antioxidative effects of rice bran extracts on refined tuna oil during storage. Food Res Int. 2008;41:616622.

3. Khanipour AA, Etemadian Y, Zareh Gh, Noghani F, Rafieepour F, Kamali S, et al., 2016. The production of dried products from tiny shrimp (Macrobrachium nipponense) of International Bandar Anzali lagoon. Research project. Iranian Fisheries Science Research Institute. 2016;1-107.

4. Li Z H, Wang J X, Xie S. Functions of environmental factors in shrimp aquaculture. Reservoir Fisheries. 2004;24:1-4.

5. Ma K, Feng J, Lin J, Li J. The complete mitochondrial genome of Macrobrachium nipponense. J Gene. 2011;487:160-165.

6. Bandani Gh, Khoshbavar Rostami H, Keymaram F, Sadighi O, Mirshekar D. The first report of shrimp Mcrobrachium nipponense Alagol, Almagol and Ajigol Lagoons Golestan Province. Iranian J Fisheries Sci. 2013;22:164-170.

7. De Grave S, Ghane A. The establishment of the Oriental River Prawn Macrobrachium nipponense (de Haan, 1849) in Anzali Lagoon, Iran J Aquatic Invasions. 2006;1:204-208.

8. Zaregashti Gh, Etemadian Y, Khanipour AA, Noghani F. The shelf-life of Macrobrachium 
nipponense dried meats during six months storage at room temperature. J Fisheries Res. 2018;2:7-16.

9. Teeboonma U, Tiansuwan J, Soponronnarit S. Optimization of heat pump fruit dryers. J Food Engineering. 2003;59:369-377.

10. Namsanguan Y, Tia W, Devahastin S, Soponronnarit S. Drying kinetics and quality of shrimp undergoing different two-stage drying processes. Drying Tech, An Int J. 2004;22:759-778.

11. Castro FAFD, Sant' Ana, HMP, Campos FM, Costa NMB, Silva MTC, Salaro AL, Franceschini CDCC. Fatty acid composition of three freshwater fishes under different storage and cooking processes. J Food Chem. 2007;103:1080-1090.

12. AOAC. Official methods of analysis. Washington DC. USA. Horowitz. 2005.

13. Niamnuy C, Devahastin S, Soponronnarit S. Quality changes of shrimp during boiling in salt solution. J Food Sci. 2007;72:289-297.

14. Parvaneh V. Quality control and the chemical analysis. University of Tehran Press, Tehran. 2007.

15. USDA. United States Department of Agriculture. http://www.ams.usda.gov/fv/ppbweb/PPBfilecodes/1 35a19/. 2006.

16. Wu W, Huff HE, Hsieh F. Processing and properties of extruded flaxseed-corn puff. J Food Processing. Preservation. 2007;2:211-226.

17. Tarladgis BG, Watts BM, Younathan MT. A distillation method for the quantitative determination of malondialdehyde in rancid foods. J American Oil Chemist Society. 1960;37:44-48.

18. Woyewoda AD, Shaw SJ, Ke PJ, Burns BG. Recommended laboratory methods for assessment of fish quality. Halifax, Nova Scotia.1986.

19. Meilgaard MC, Civille GV, Carr BT. Sensory evaluation techniques. CRC Press, Taylor and Francis Group. USA. 2007.

20. Selmi S, Bouriga N, Cherif M, Toujani M, Trabelsi M. Effects of drying process on biochemical and microbiological quality of silverside (fish) Atherina lagunae. Int J Food Sci. Nut. 2010;45:1161-1168.

21. Sriket P, Benjakul S, Visessanguan W, Kijroongrojana K. Comparative studies on chemical composition and thermal properties of black tiger shrimp (Penaeus monodon) and white shrimp (Penaeus vannamei) meats. J. Food Chem. 2007;103:1199-1207.

22. Henna-Lu FS, Nielsen NS, Timm-Heinrich M, Jacobsen C. Oxidative stability of marine phospholipids in the liposomal form and their applications. Lipids. 2011;46:3-23.
23. Sampaio GR, Bastos DHM, Soares RAM, Queiroz YS, Torres EAFS. Fatty acids and cholesterol oxidation in salted and dried shrimp. J Food Chem. 2006;95:344-351.

24. Akonor P, Ofori H, Dziedzoave N T, Kortei N K. Drying Characteristics and Physical and Nutritional Properties of Shrimp Meat as Affected by Different Traditional Drying Techniques. Int J. Food Sci. 2016;1:1-5.

25. Wu T, Mao L. Influences of hot air drying and microwave drying on nutritional and odorous properties of grass carp (Ctenopharyngodon idellus) fillets. J Food Chem. 2008;110:647-653.

26. Kamalakar D, Nageswara Rao L, Siva Prasada Rao K, Venkateswara Rao M. Studies on Drying Characteristics of Prawn and Fish. J. Chem, Biological. Physical Sci. 2013;3:1972-1982.

27. Modi VK, Sachindra NM, Nagegowda P, Mahendrakar N, Rao DN. Quality changes during the storage of dehydrated chicken kebab mix. Int J Food Sci.Tech. 2007;42:827-835.

28. Gomes HA, Silva EN, Nascimento MRL, Fukuma HT. Evaluation of the 2- thiobarbituric acid method for the measurement of lipid oxidation in mechanically deboned gamma irradiated chicken meat. J Food Chem. 2003;80:433-437.

29. IRI. Microbiology of food and animal feeding stuffs - Guideline of general requirements for examination. Institute of Standards and Industrial Research of Iran (IRI). 2007;9899.

30. Xue-yun T, Jie C, Geng-geng LI, Li-juan Z, Yanfeng D. Effect of processing conditions on the nutrition value of fish soup. Sci Tech Food Industry. 2008;10:248-251.

31. Rezaei M, Hosseini SF. Quality Assessment of Farmed Rainbow Trout (Oncorhynchus mykiss) during Chilled Storage. J Food Sci. 2008;73:93-96.

32. Fan W, Sun J, Chen Y, Qiu J, Zhang Y, Chi Y. Effect of chitosan coating on quality and shelf life of silver carp during frozen storage. J. Food Chem. 2009;115:66 -70.

33. Kilinc B, Cakli S. Determination of the shelf life of sardine (Sardina pilchardus) marinades in tomato sauce stored at $4^{\circ}$ C. J Food Control. 2005;16:63944.

34. Lopez-Caballero ME, G'omez-Guill'en MC, P'erezMateos M, Montero P. A chitosan-gelatin blend as a coating for fish patties. J Food Hydrocolloids. 2004;19:303-311.

35. Gimenez B, Roncales P, Beltran JA. Modified Modified atmosphere packaging of filleted rainbow trout. J Sci Food Agri. 2002;82:1154-1159. 
36. Mol S. Preparation and the shelf-life assessment of ready-to-eat fish soup. European Food Res Tech. 2005;220:305-308.

37. Chacko D, Renitta RE, Patterson J. Development of soup power from squid Sepioteuthis lessoniana and shelf-life assessment during storage in laminated packaging material. J Food Tech. 2005;3:449-452.

38. Taghizadeh GH, Rezaei M. Effect of gelatin coatings on chemical, microbial and sensory properties of refrigerated rainbow trout fillet (Oncorhynchus mykiss). 2012;9:67-76.
39. Silva S, Negri M, Henriques M, Oliveira R, Williams DW, Azeredo J. Adherence and biofilm formation of non-Candida albicans Candida species. Trends Microbiol. 2011;19:241-247.

40. ICMSF. International Commission on Microbiological Specification for Foods. Microorganisms in foods. 2. Sampling for microbiological analysis: principle sand specific applications (2nded.). Buffalo, NY: University of Toronto Press. 1986. 